\section{Beyond Academic and Social Integration: Understanding the Impact of a STEM Enrichment Program on the Retention and Degree Attainment of Underrepresented Students}

Tonisha B. Lane*

Department of Leadership, Counseling, Adult, Career, and Higher Education, University of South Florida, Tampa, FL 33620

\begin{abstract}
The current study used a case study methodological approach, including document analysis, semistructured interviews, and participant observations, to investigate how a science, technology, engineering, and mathematics (STEM) enrichment program supported retention and degree attainment of underrepresented students at a large, public, predominantly white institution. From this study, a model emerged that encompassed four components: proactive care, holistic support, community building, and catalysts for STEM identity development. These components encompassed a number of strategies and practices that were instrumental in the outcomes of program participants. This paper concludes with implications for practice, such as using models to inform program planning, assessment, and evaluation.
\end{abstract}

\section{INTRODUCTION}

Advancing the success of students of color in science, technology, engineering, and mathematics (STEM) is a pressing and complex issue. There are several trends (e.g., changing demographics, aging workforce, and globally competitive market) that necessitate increasing the number of underrepresented groups in the STEM workforce. Underrepresented groups make up a significantly smaller percentage $(13 \%)$ of the STEM workforce when compared with whites (71\%; National Science Foundation [NSF], 2015). Blacks and Hispanics are also more likely to be employed in scienceand engineering-related occupations (e.g., health technologists) than in science and engineering (e.g., physical scientist, engineer). Additionally, whereas white women constitute $20 \%$ of the science and engineering workforce, underrepresented women represent $\sim 10 \%$ of individuals employed in these professions (NSF, 2015). Such participation gaps in the STEM workforce illustrate the importance of increasing undergraduate retention and degree attainment, among other efforts.

Significant attention has been devoted to the recruitment and retention of underrepresented students in STEM fields (National Academy of Sciences, National Academy of Engineering, and Institute of Medicine, 2010). Yet their graduation rates are consistently lower than majority graduates. Only 15\% of African Americans, $16 \%$ of Hispanics, and $<1 \%$ of Native Americans earn a STEM bachelor's degree in 6 years, compared with $30 \%$ of whites (Chen, 2009). STEM enrichment program represent one mechanism that has been used to bolster the achievement of underrepresented students. These programs often entail structured academic support in the form of academic advising, mentoring, and tutoring (Tsui, 2007). While there is a growing body of literature on these programs, few studies theorize why certain strategies work to increase student retention.
Pat Marsteller, Monitoring Editor Submitted January 16, 2016; Revised May 2, 2016: Accepted June 7, 2016

CBE Life Sci Educ September 1, 2016 15:ar39 DOI:10.1187/cbe.16-01-0070

*Address correspondence to: Tonisha B. Lane (tblane@usf.edu).

(C) 2016 T. B. Lane. CBE-Life Sciences Education (C) 2016 The American Society for Cell Biology. This article is distributed by The American Society for Cell Biology under license from the author(s). It is available to the public under an Attribution-Noncommercial-Share Alike 3.0 Unported Creative Commons License (http://creativecommons.org/ licenses/by-nc-sa/3.0)

"ASCB®" and "The American Society for Cell Biology $\circledR^{\circledR}$ are registered trademarks of The American Society for Cell Biology. 
Previous studies that have investigated STEM enrichment programs have found it difficult to determine why these programs contribute to successful outcomes for their students. For instance, Watson and Froyd (2007) studied engineering intervention programs and developed three categories of classification: 1) interventions that focused on community building by creating and sustaining networks to encourage peer support; 2) interventions focused on cognitive development that are designed to assess deficits in academic ability and methods to improve them; and 3) interventions that concentrate on vocational interests and exposure to careers and practice. Watson and Froyd (2007) contended that determining the effectiveness of an intervention may be challenging because of the difficulty in extrapolating the factors that are impactful in achieving student success. Further, program administrators would benefit from having a theoretical understanding of how and why these programs work to inform practice and future research.

The purpose of this study was to generate a new model for understanding how a STEM enrichment program supports the retention and degree attainment of underrepresented students at a large, public, predominantly white institution (PWI). The questions that guided this study were, How does a STEM enrichment program aid in the retention and degree attainment of underrepresented students? and What strategies and practices does the program employ to facilitate academic and social adjustment? Much of the existing literature focuses on why students leave the STEM disciplines (Seymour and Hewitt, 1997), but few empirical studies explore the environmental influences that contribute to their persistence and degree completion (Museus and Liverman, 2010). Additionally, educational researchers suggest there is a need for more rigorous qualitative studies that provide in-depth analysis and illuminate the nuances and complexities of STEM intervention programs (Museus et al., 2011).

In this study, underrepresented groups included AfricanAmericans, Latino, and southeast Asian-American students. With respect to this last group, researchers have begun to include some Asian-American subgroups as an underrepresented population due to their low rates of college degree attainment (Museus, 2014).

In this article, I provide a brief overview of previous theoretical models and frameworks that have been used to examine the successful outcomes of underrepresented groups in higher education and explain why certain approaches broaden participation in the STEM disciplines. Then, I present a model that emerged from a qualitative case study of a STEM enrichment program at a large, public PWI that was influential in the successful outcomes of underrepresented students. Finally, I offer implications of the model for practice and future research.

\section{LITERATURE REVIEW AND CONCEPTUAL FRAMEWORK}

The literature provides both theoretical and practical perspectives concerning how underrepresented students succeed in postsecondary education and, specifically, in the STEM disciplines. Some literature identifies the kinds of knowledge that students need to succeed in a college setting (Treisman, 1992; Seymour and Hewitt, 1997; Tsui, 2007). The literature also argues that students' sense of belonging, such as feeling cared for or connected to the university, is a vital aspect of their success (Hurtado and Carter, 1997; Hausmann et al., 2009;

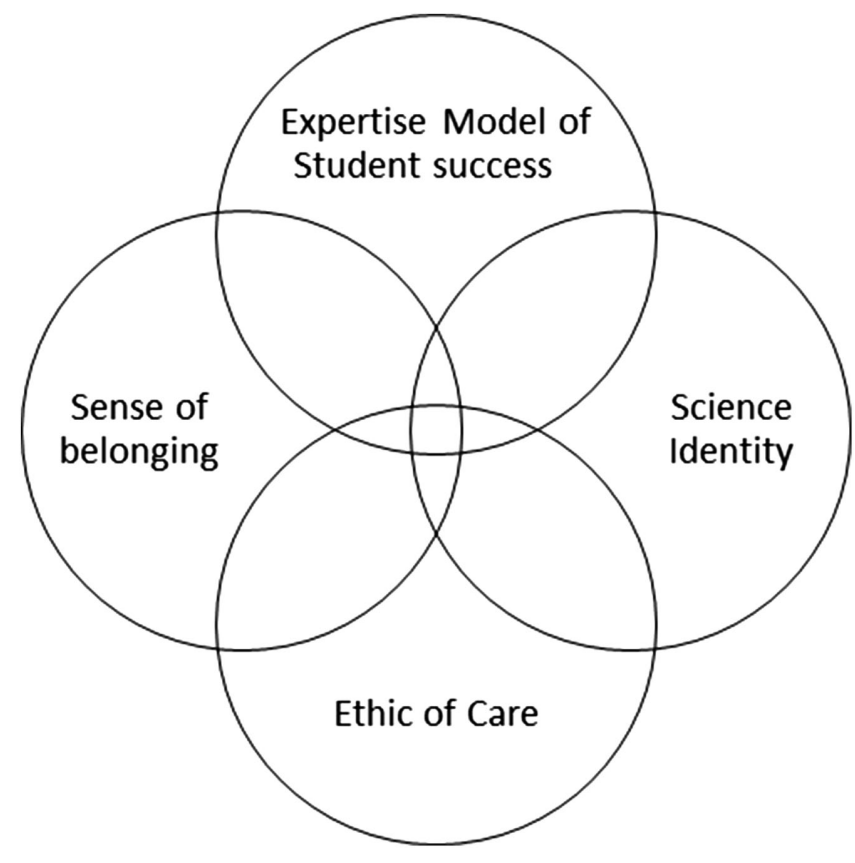

FIGURE 1. Conceptual framework.

Strayhorn, 2012). Other studies point to science identity development as an important factor for student retention. Students who establish a sense of identity and see themselves as scientists or emerging scholars are more likely to persist (Chemers et al., 2011; Hurtado et al., 2011; Eagan et al., 2013; Merolla and Serpe, 2013). More recent scholarship has examined an ethic of care as a guiding practice in intervention programs for underrepresented groups (Manning et al., 2006). The literature would suggest that the integration of these concepts might provide insight into the efficacy and utility of STEM enrichment programs. Thus, this study applied concepts from the following frameworks: the expertise model of student success (EMSS; Padilla, 2009), sense of belonging (Strayhorn, 2012), science identity (Carlone and Johnson, 2007), and ethic of care (Gilligan, 1982; Noddings, 1984; Manning et al., 2006) to understand how one STEM enrichment program aids in the retention and degree attainment of underrepresented groups (see Figure 1).

\section{Student Success}

The EMSS is a theoretical model that "presents a particular understanding of student success by bringing together a set of concepts and the relationships that connect them" (Padilla, 2009, p. 8). Raymond Padilla (2009) designed this model to counter previous frameworks that had emphasized student attrition, such as Tinto's $(1987,1993)$ theory of student departure. Padilla asserted that previous frameworks focused on student departure to ascertain methods for retaining students. However, this approach inhibited scholars and practitioners from exploring what contributed to successful student outcomes (Padilla, 2009).

Padilla (2009) posited that college educators are familiar with two elements of the college student experience: student inputs and outputs. Student experiences and backgrounds 
coming into the institution and their outcomes of graduation or attrition are known or can be determined qualitatively or quantitatively. However, the campus or institutional experience that students encounter is relatively unknown and is therefore sometimes referred to as the black box. Padilla (2009) asserts there are barriers in any institution that hinder students from being successful. To overcome these barriers, students must acquire a combination of context-specific and academic knowledge.

On the basis of studies conducted with Latino students, Padilla (2009) concluded that students begin their college careers with initial knowledge about the college experience, but they must acquire total knowledge (i.e., academic and context specific) to successfully complete college. Academic knowledge is campus independent. It includes information garnered from classroom learning, such as laws, axioms, principles, and theories. In contrast, heuristic knowledge is campus dependent; this knowledge can be obtained through experiential learning. Context-specific or heuristic knowledge may be considered the "rules of thumb" at a given institution. They include navigating financial aid or understanding the academic advising system (Padilla, 2009). Moreover, successful students will realize what gaps exist in their knowledge base, both heuristic and academic, and take effective actions to obtain that knowledge and complete necessary tasks to advance within the institution.

\section{Sense of Belonging}

Strayhorn (2012) posited that "sense of belonging refers to a student's perceived social support on campus, a feeling or sensation of connectedness, the experience of mattering or feeling cared about, accepted, respected, valued by, and important to the group (e.g., campus community) or others on campus (e.g., faculty, peers). It is a cognitive evaluation that typically leads to an affective response or behavior" (p. 3). Thus, an emotional connection to an environment and the people within it can motivate an individual to engage in educationally purposeful activities leading to successful outcomes (Strayhorn, 2012).

Research shows having a sense of belonging may contribute to better academic and social adjustment in college (Hurtado and Carter, 1997; Locks et al., 2008; Hausmann et al., 2009; Strayhorn, 2012). In a quantitative study using a national, multi-institutional data set, Locks and colleagues (2008) found that positive interactions with diverse peers contributed to a greater sense of belonging for students transitioning into college. Similar findings were discovered for Latino students in their interactions with diverse peers in the residence halls (Johnson et al., 2007). Additionally, Johnson and colleagues (2007) found that the quality and frequency of these interactions enhanced students' sense of belonging. Programs that create opportunities for engagement among diverse students are essential for providing a supportive environment. Research also suggests that these opportunities may contribute to student retention and academic achievement (Hausmann et al., 2009).

Students who have a sense of belonging transition better into their institutions. Johnson and colleagues (2007) examined sense of belonging among first-year undergraduate students. It was discovered that students who made a "smooth social transition" from high school to college felt a greater sense of belonging in their institutions (p. 537). This study also uncovered that faculty, staff, and peers play critical roles in cre- ating supportive environments for students transitioning into college. Thus, Johnson and colleagues' (2007) findings "suggest that a more appropriate goal may be attending to students' sense of belonging through nurturing a mutual responsibility shared by the institution and individual" (p. 537).

\section{Science Identity}

There is a growing body of literature exploring science identity and the role STEM enrichment programs play in cultivating a student's science identity (Chemers et al., 2011; Hurtado et al., 2011; Eagan et al., 2013; Merolla and Serpe, 2013). Carlone and Johnson (2007) first conceptualized science identity from their work investigating successful female undergraduate and graduate students of color. They discovered the saliency of three components that contributed to the strong science identity of these women: performance, recognition, and competence. Performance is the ability to conduct "relevant scientific practices," such that one demonstrates acquisition of academic language (e.g., scientific or professional terminology) and use of tools (e.g., laboratory materials and apparatuses). Recognition entails being acknowledged as a "science person" by one's self and "meaningful others," such as faculty or scholars in the field. Competence consists of knowledge attainment and comprehension of science content; this construct may be less observable than performance (Carlone and Johnson, 2007).

Building social relationships is critical to developing one's science identity. Because some underrepresented students lack personal and professional networks in the STEM disciplines, they may be more apt to leave these fields during college and after earning their degrees (Merolla and Serpe, 2013). For instance, Treisman (1992) discovered that black students underperformed in their math courses in comparison with Asian students, largely because they did not study with other students. Once he established a structured program to facilitate interactions around the common interest of succeeding in mathematics, many of the black students outperformed black nonparticipants and the general student body in the college of engineering of engineering (Treisman, 1992).

Studies also show underrepresented students who participate in undergraduate research are more likely express intentions to pursue graduate or professional education (Eagan et al., 2013) and subsequently enroll in these programs (Merolla and Serpe, 2013). Using inferential statistics, Eagan and colleagues (2013) were able to demonstrate that participation in undergraduate research significantly influenced minority students' intentions to enroll in graduate education. Undergraduate research programs help students build important networks for academic and professional success and science identity development (Carlone and Johnson, 2007; Merolla and Serpe, 2013). Given these findings, researchers argued that postsecondary institutions should do more to ensure there is an equitable representation of underrepresented students in these types of programs through addressing impediments to access and STEM pathways.

\section{Ethic of Care}

Gilligan's (1982) research on moral development advanced a caring perspective with attention to the value of relationships, connections, and interdependence in decision making and responsiveness. Building on Gilligan's work, Noddings (1984) 
applied notions of care to educational environments, suggesting that caring relationships can be instrumental in supporting student achievement. According to Noddings (1984), a caring relationship requires that the caregiver (e.g., administrator) understands the cared for (e.g., student) from his or her perspective. For instance, Noddings (1984) asserted that engrossment and motivational displacement are components of the caring relationship. Engrossment entails being sympathetic toward students' circumstances. Motivational displacement posits that "when I care ... my motive energy flows toward the other and perhaps, although not necessarily, toward his ends ... I allow my motive energy to be shared; I put it at the service of the other" (p. 33). As a result, the caregiver minimizes his or her needs to advance the needs of the student.

In higher education scholarship, the Documenting Effective Education Practice project (DEEP) was a 2-year study of effective educational practices in postsecondary institutions (Kuh et al., 2010). On the basis of National Survey for Student Engagement (NSSE) data, researchers identified institutions with high rates of engagement given their student populations and institutional characteristics (i.e., size, selectivity, location; Kuh et al., 2010). One successful model that emerged from this study was the "student-centered ethic of care model" (Manning et al., 2006, p. 98). Manning and colleagues posited that this model focused on "care and relationships" (p. 98). They cited Gilligan (1982) and Noddings (1984) as undergirding this form of practice in "response to student needs; services geared toward the goal of facilitating student success; integrated services, policies, and programs, and practice centered on an ethic of care" (Manning et al., 2006, pp. 98-99).

Program administrators who employ the ethic of care model recognize that some students have been historically underserved by the educational system. Thus, practitioners provide students with the academic and social skills necessary to succeed in college. Institutions may apply this model to the implementation of programs and services such as orientations programs and college success seminars. Some of the strengths of this model are the availability of carefully crafted resources, time devoted to students, and belongingness experiences (Manning et al., 2006).

The integration of the aforementioned research and theoretical frameworks was used as an analytical lens to investigate the STEM enrichment program in the current study. The merging of these concepts into one conceptual framework was an alternative approach to the often-cited theory of college student departure (Tinto, 1975, 1987, 1993), which posits that college students' "academic and social integration" into the university is central to student retention (Maton et al., 2000; Stolle-McAllister et al., 2011). Over the years, education scholars have revised (Rendon et al., 2000) and critiqued (Tierney, 1992) this theory for its shortcomings. Consequently, Tinto's model has been modified three times $(1975,1987,1993)$ amid criticism regarding its comparison of student departure with Durkheim's notions of suicide (Hurtado and Carter, 1997). There were also concerns raised about the clarity and uniformity of constructs, academic and social integration, and propositions about separation from prior communities as a precursor to college integration (Hurtado and Carter, 1997). Most importantly, Braxton (2000) argued that Tinto's framework may not be inclusive of the increasing diversity on college campuses and the academic and social realities of nontraditional students in these environments. Such critiques suggest that alternative models may be more appropriate for examining the success of underrepresented students in STEM.

\section{METHODS}

I conducted an explanatory, holistic, single case study (for a description of this type of study, see Yin, 2003) that investigated the influence of a STEM enrichment program, the Comprehensive STEM Program (CSP), on the retention and degree attainment of students of color in the STEM disciplines at Jefferson State University (JSU). (Both Jefferson State University/ JCU and Comprehensive STEM Program/CSP are pseudonymous.) The purpose of this study was to advance the existing literature by explaining how STEM enrichment programs like CSP aid in the retention and degree attainment students of color (Yin, 2003). In this study, qualitative data were used both to understand the STEM enrichment program and how it influences the outcomes of the students. These data sources included interviews, participant observations, and documents. (See the Supplemental Material for interview protocols.)

\section{Institutional and Program Context}

JSU is a large, public, land-grant research university in the Midwest. Each year, half of newly admitted students declare a major in the STEM disciplines. In Fall 2013, 9\% were students of color. Approximately $61 \%$ of all STEM students complete their degrees within 6 years compared with $43 \%$ of students of color.

The CSP, a STEM enrichment program at JSU, was established in 2007 with an NSF Louis Stokes Alliance for Minority Participation (LSAMP) grant to acclimate first-year students to the rigorous academic culture and college life in the STEM disciplines. The program also has a stated mission to retain students from academically and economically disadvantaged backgrounds in the STEM disciplines. CSP contains eight program components: a summer bridge program, residential housing, tailored university math courses, weekly recitation sessions, peer mentoring, academic advising, freshman seminar, and an undergraduate research experience. The program capacity is 50 students.

\section{LSAMP}

CSP is partially funded through LSAMP, a national program organized through statewide alliances or consortiums. The LSAMP program was established in 1991 at NSF based on a congressional mandate. LSAMP began with six alliances, and currently boasts more than 40 alliances representing more than 600 institutions with more than 400,000 LSAMP participants who have earned BA/BS degrees in STEM disciplines (Barrena and Veden, 2013). A. James Hicks indicated,

The goals of LSAMP are to significantly increase the quality and quantity of minorities who successfully complete baccalaureate degrees in science, technology, engineering, and mathematics (STEM), and to increase the number of minority students who continue to graduate studies in these fields. (Barrena and Veden, 2013, 3:57 min)

The LSAMP program emphasizes "innovative recruitment and retention strategies and experiences in support of groups 
TABLE 1. Retention and graduation data of program participants

\begin{tabular}{lccccccc}
\hline & $\mathbf{2 0 0 7}$ & $\mathbf{2 0 0 8}$ & $\mathbf{2 0 0 9}$ & $\mathbf{2 0 1 0}$ & $\mathbf{2 0 1 1}$ & $\mathbf{2 0 1 2}$ & $\mathbf{2 0 1 3}$ \\
\hline Participants & 20 & 14 & 23 & 18 & 18 & 21 & 41 \\
STEM retention & $70 \%$ & $64 \%$ & $70 \%$ & $72 \%$ & $67 \%$ & $81 \%$ & $71 \%$ \\
Persisting & - & - & $78 \%$ & $77 \%$ & $78 \%$ & $95 \%$ & $83 \%$ \\
Degrees earned from JSU & $90 \%$ & $79 \%$ & - & - & - & - & - \\
\hline
\end{tabular}

Based on data-collection period of Summer 2013-Spring 2014.

that are historically underrepresented in STEM disciplines: African Americans, Alaskan Natives, American Indians, Hispanic Americans, Native Hawaiians, and Native Pacific Islanders" (Barrena and Veden, 2013, 40 s). According to Dr. Joseph Bordogna (2012), former deputy director and chief operating officer of the NSF, "LSAMP students account for $70 \%$ of all minority baccalaureates in science and engineering" (para. 20). In a (Westat, 2000) report, the authors identified six essential factors that contribute to the success of LSAMP, including summer bridge programs, drop-in centers, mentoring, caring staff, research experience, and alliance structure. As discussed further in the next section, CSP reflects LSAMP's goals and successful practices through their array of programs and services geared toward underrepresented groups in STEM.

\section{CSP}

The CSP at JSU began in 2007 to acclimate first-year students to the academic, psychosocial, and environmental aspects of postsecondary education. The program was designed to ensure the success of students pursuing a rigorous, STEM-focused curriculum. Specifically, the program sought to support students until they were admissible into their given colleges. At JSU, there is a dual admissions process. As such, students are first admitted to JSU, and by junior status (or 56 credits), they must meet specific criteria to be admissible to their particular colleges. For example, in the College of Engineering and Computer Science, students are required to complete core courses (e.g., mathematics, physical and biological sciences, and introductory engineering courses) and attain a specific grade point average (GPA). There is a slight variation in core course and GPA requirements contingent upon one's discipline. The remaining STEM-affiliated colleges require that a student make adequate progress toward his or her selected degree with a $2.0 \mathrm{GPA}$ or greater. Due to these admission policies and CSP's goals, most students engage in the program for 2 years, but there are some students who stay connected until they graduate from the university.

I selected CSP for several reasons. In the first year of implementation of this program, 95\% of students were retained throughout the third semester (i.e., sophomore year). Also, $70 \%$ of the first cohort attained a STEM degree, and $64 \%$ of the 2008 cohort earned a STEM degree (see Table 1). In compari- son, one study reports 4-year graduation rates for underrepresented groups in STEM at selective institutions as low as $7.6 \%$ (Hayes, 2002). Finally, over a 2 -year period, more than $85 \%$ of the students increased their math placement exam scores after the conclusion of the summer bridge program (see Table 2). Such outcomes have implications for time to degree and STEM degree attainment.

\section{CSP's Recruitment Process and Program Components}

Admitted students declaring a major in a STEM degree-granting program at JSU are selected to receive CSP recruitment materials based on one of three criteria: 1) students are admitted to the university through a special admissions process geared toward first-generation and low-income students, 2) students declare a major in STEM with a math placement below calculus, and 3) students declare a major in STEM and express interest, in writing, to the program coordinators. A month before the start of the summer bridge program, staff invite applicants and their families to a 1-day recruitment event. At the recruitment day, program staff meet with applicants and families, provide more information about the program, and conduct interviews with the applicants. The applicants also complete a noncognitive questionnaire (Sedlacek, 2004). Approximately 2 weeks later, staff invite the selected applicants to participate in CSP.

All program components are mandatory; students are not allowed to opt out of any of the program components, or they will be dismissed from the entire program. Any student who successfully completes the first year of the program receives a $\$ 1000$ scholarship during his or her sophomore year. There is no cost to the student for participation in the program. The following section provides an overview of the program components (see Figure 2).

Summer Bridge Program. The summer bridge program is a 6-week academically intensive and socially engaging experience that introduces students to the academic culture and campus life at JSU. Students live in the residence halls, attend classes (i.e., mathematics, chemistry or biology, writing) and workshops (i.e., academic and professional development), and participate in social activities and community service.

TABLE 2. Math placement increases and course movements

\begin{tabular}{lcccccc}
\hline Cohort & $\boldsymbol{N}$ & $\begin{array}{c}\text { Increased math } \\
\text { placement score }\end{array}$ & $\begin{array}{c}\text { Placed into a higher } \\
\text { math course }\end{array}$ & $\begin{array}{c}\text { Intermediate algebra } \\
\text { to algebra }\end{array}$ & $\begin{array}{c}\text { College algebra } \\
\text { to precalculus }\end{array}$ & $\begin{array}{c}\text { Precalculus } \\
\text { to calculus }\end{array}$ \\
\hline 2012 & 21 & $88 \%$ & $59 \%$ & $60 \%$ & $100 \%$ & $50 \%$ \\
2013 & 41 & $94 \%$ & $70 \%$ & $79 \%$ & $100 \%$ & $42 \%$ \\
\hline
\end{tabular}

aNot all those who increased the math placement score moved to the next course. 


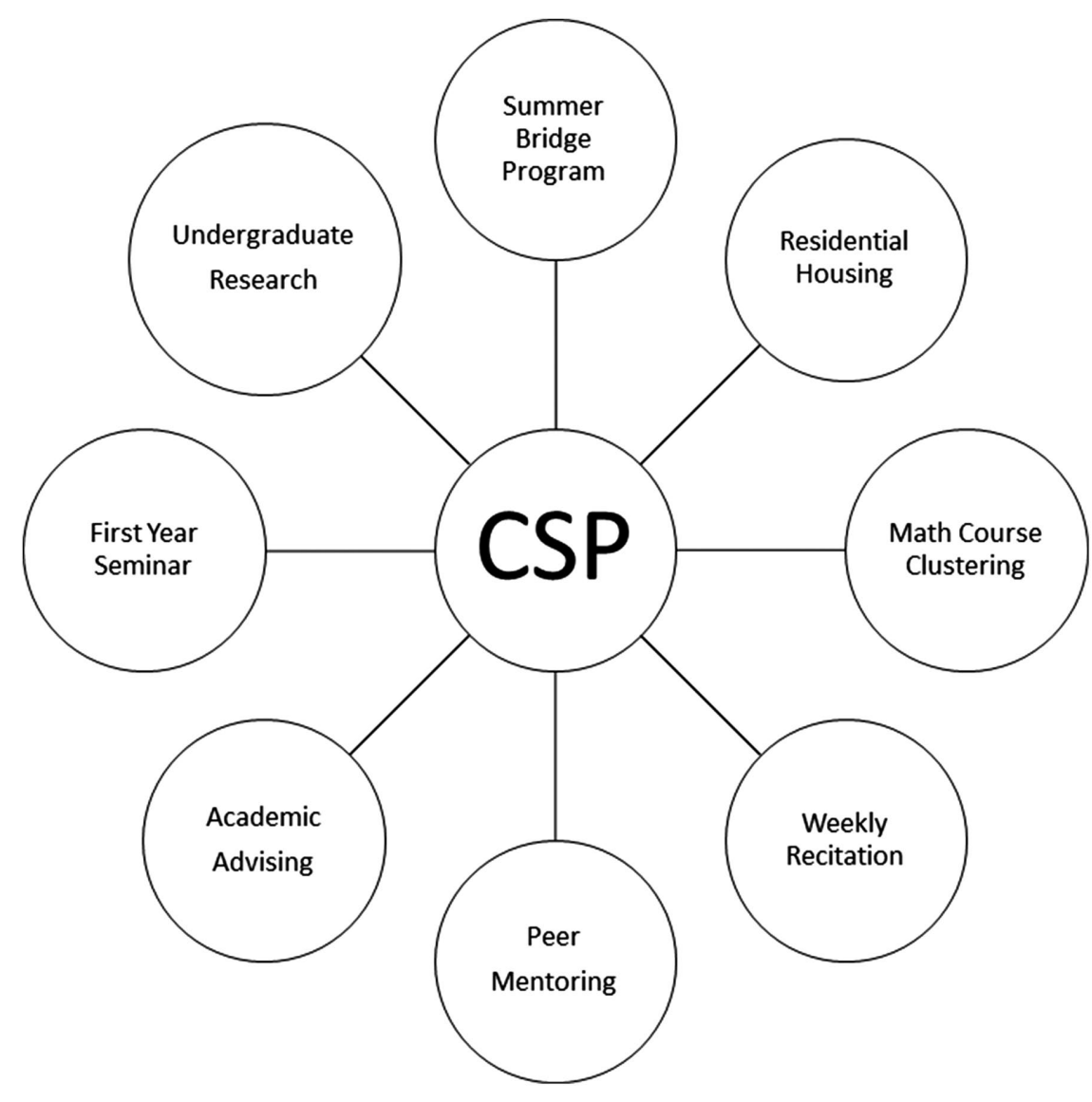

FIGURE 2. CSP program components.
First-Year Seminar. This course serves as continuation to the academic, personal, and professional development that begins in the summer bridge program. Course topics and assignments include transitional problems, communication skills, conducting presentations, career assessments, writing assignments, developing a product or service that addresses a STEM problem, and a term paper about achieving academic and professional goals.

Residential Assignment. Program participants live in the same residence hall during their first year. CSP coordinates with residential staff to assign program participants as roommates, to the same floor, and/or the same side of the residence hall.

Peer Mentoring. Upperclassmen serve as peer mentors. Not all mentors are former CSP participants. If a qualified student expresses interest, he or she can become a mentor. Mentoring promotes peer accountability and serves as an additional campus resource. Mentor and protégé matching occurs through responses to a short survey about majors, academic and nonacademic interests, and professional goals. Peer mentors and program participants make regular contact through formal and informal gatherings.
Biweekly Advising. Students meet with a CSP administrator twice a month for at least $30 \mathrm{~min}$. During these advising sessions, students complete a survey to document their academic performance and identify any nonacademic concerns they are experiencing. They must also report their attendance, grades on exams, assignments, actual grades, desired grades, and actions that should be taken to improve their grades.

Recitation Sessions. Recitation sessions are held in an academic building Monday to Thursday from 7:00 pm to 9:30 pm. Paid academic assistants (upper-division undergraduate students) assist program participants with their chemistry and mathematics courses and assignments in one-on-one or group configurations. Additionally, many of the program participants support one another with learning and understanding course content and scientific concepts.

Selected STEM Sections of Math and Science Courses. On the basis of math placement and availability, some program participants enroll in sections with smaller class sizes to promote networking and a shared experience among the participants. With permission from the participants, program administrators collaborate with faculty to monitor their academic performance on assignments and exams and follow up with students during their academic advising sessions.
Undergraduate Research Opportunity. Staff select students who successfully complete the first year of the program to participate in a summer residential research assistant position. CSP staff coordinate student placement in collaboration with the College of Life and Physical Sciences, NSF-funded undergraduate mathematics research program, and the graduate school's Summer Research Opportunity Program. Students receive a stipend ranging from $\$ 1100$ to $\$ 3500$, conduct research with a faculty member for 4-8 weeks, conduct an oral and poster presentation, and complete a written report.

\section{Participants}

There were 50 participants in the current study: 42 current and former program participants, two administrators, two instructors, and four recent baccalaureate recipients and former program participants. The 46 student and alumni participants represented various STEM majors, including biology, physiology, and various engineering fields. The average firstyear GPA was 3.01. There were two southeast Asian-American, four Latina, and 40 African-American students and alumni. Approximately $41 \%$ of the participants were women. Also, about half of the participants were lower-income and first-generation college students. All of the administrators and instructors were African American, and all of them were male, except for one female instructor. 


\section{Data Collection}

This study is based on data collected from June 2013 to April 2014 (IRB x13-553e). The data-collection process entailed focus groups and individual interviews, participant observations (e.g., class sessions, recitation sessions, meetings, advising sessions, and study spaces), and analyzing documents (e.g., evaluations, marketing materials, program's Web content).

Focus groups and interviews lasted 30-80 min. Current and former (i.e., baccalaureate recipients) program participant interviews focused on experiences within the university and program, elements that supported or hindered belongingness, influential factors in their STEM identity development, and notions of care. Individual interviews with the program and assistant program director and instructors were used to learn more about the infrastructure of the program and effective strategies and practices and to corroborate findings from student interviews.

\section{Data Analysis}

Focus group and individual interviews were transcribed verbatim by a professional transcriptionist and checked for accuracy. During the initial coding process, I used participants' terms and phrases to name or categorize data generated from the interviews. This coding process is referred to as "in vivo coding" (Charmaz, 2008). Because the purpose of the study was to develop a model to explain how a STEM enrichment program supports retention and degree attainment, I used an axial coding technique with the initial codes to create categories and subcategories that provided explanatory evidence. These revised categories provided a basis for the theoretical coding that eventually allowed me to show linkages between program components, activities, and philosophies and student experiences and outcomes (Charmaz, 2008).

\section{LIMITATIONS}

The design of this study does contain some limitations that should be noted. The qualitative methods used in this study limit the generalizability of the findings. While this study closely aligns with literature regarding the experiences and perceptions of underrepresented groups in STEM, these findings will need to be confirmed through additional studies. This study took place at one institutional site, and it excluded students who did not participate in CSP. Thus, findings may not reflect the experiences of nonparticipants. Additionally, because the purpose of the study was to develop a model for understanding STEM enrichment programs, a comparison group was not included in the analysis. As previously stated, the students in the current study earn degrees at significantly higher rates than the national average of underrepresented minorities in STEM. Such compelling evidence motivated the researcher to focus specifically on this program to ascertain how it supports student success. Another potential limitation was the primary usage of interviews to construct the model that emerged from this study. In case study research, experiential knowledge of the participants is a valued aspect of the data-collection process (Stake, 2000). To mitigate this limitation, I used multiple data sources in this study, in the form of interviews, observations, and document analysis, to strengthen the trustworthiness of the findings.

\section{FINDINGS}

The findings from this study produced a multifaceted model for understanding the role of STEM enrichment programs in broadening participation in science careers. The purpose of this model is not to provide a causal relationship of student outcomes and program components. However, the model illustrates how a STEM enrichment program may be influential in facilitating retention and degree attainment among underrepresented groups at a large, predominantly white, research university. An in-depth explanation of each component of this model is beyond the scope of this paper; however, Figure 3 represents how the program enables the success of underserved students of color in STEM.

\section{Holistic Support}

Students discussed how they were underprepared for college expectations, unaware of how to study for college-level STEM courses, and unfamiliar with how to create course schedules that allowed them to incrementally increase their course load as they strengthened their skills, competencies, and confidence. As one student asserted, "The program hone[s] what students need to do to be successful." The various types of holistic support that CSP provides-academic, transitional, psychosocial, practical, and professionalemerged as a central theme throughout this study. Four areas (i.e., academic, transitional, professional, and practical) were pragmatic in nature, attending to students' educational, financial, and vocational needs, but psychosocial support dealt with the nuanced racial realities of students of color in the STEM disciplines at a predominantly white institution (see Table 3).

\section{Community Building}

The characteristics that made up the community-building component were: familial atmosphere, peer relationships, relationships with staff, and peer mentors (see Table 4). Staff developed the CSP community through an infrastructure of coordinated services and activities designed to support underrepresented students in STEM. This community of scholars emerged, in part, because of their interests and connectedness to the STEM disciplines, which led to their eventual support of one another. Findings revealed that CSP staff further cultivated this community through a multitude of programmatic features such as recitation, advising, and social outings. CSP also used the peer-mentoring program to provide participants with exposure to role models and experienced students in the STEM disciplines. What emerged from this multilevel communal infrastructure is a familial atmosphere that permeates throughout the program and strengthens the relationships between staff, students, and peer mentors.

\section{Catalysts for STEM Identity Development}

While CSP staff recognized that STEM professionals were best suited to provide disciplinary training and mentoring necessary for STEM identity development and socialization into the disciplines, the staff played a complementary role in designing the program's environment and engaging students in ways that would buttress their STEM identities. These catalysts served as important mechanisms for connecting students to relevant academic and professional development 


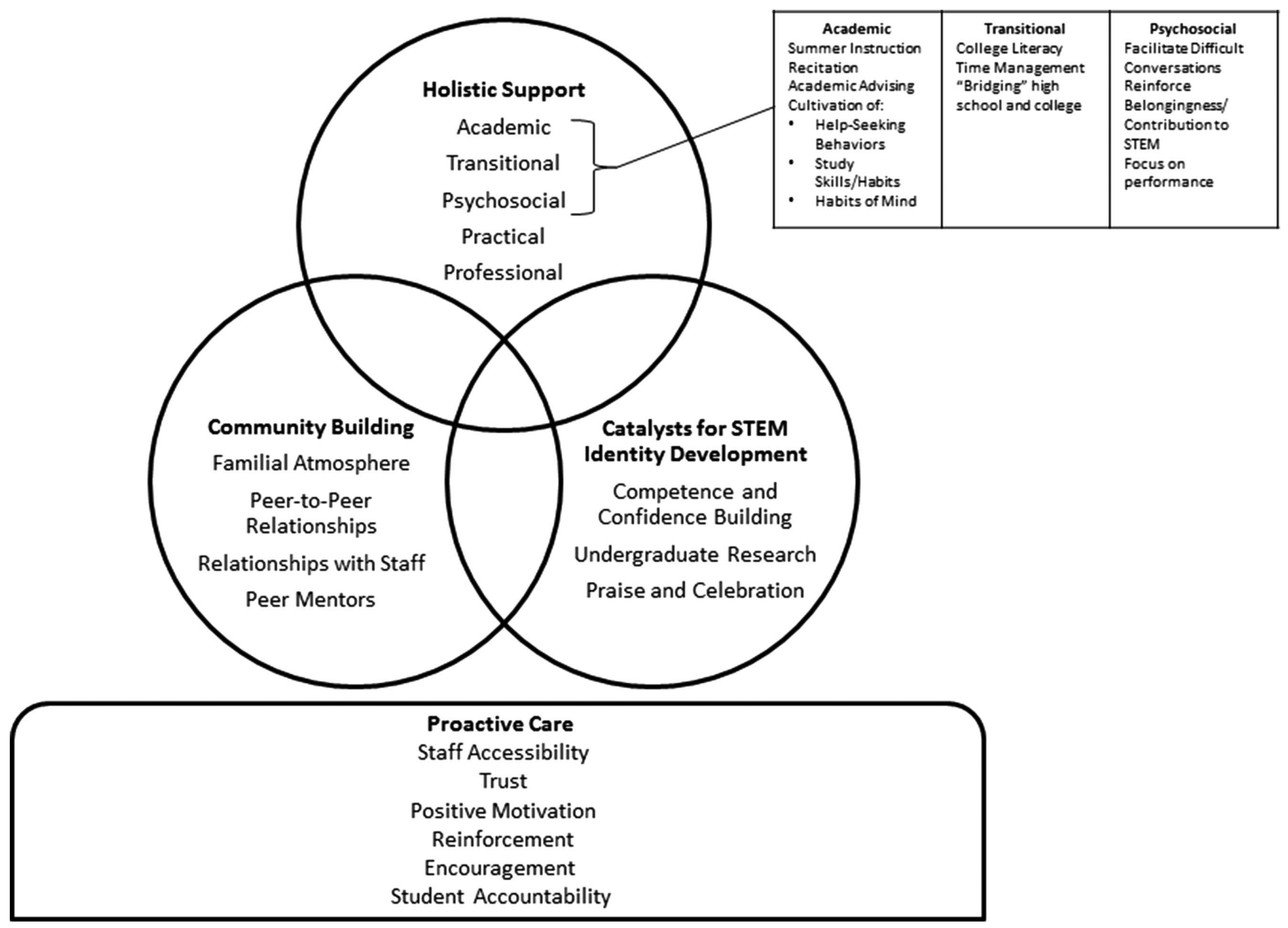

FIGURE 3. Model for programmatic impact on retention and degree attainment among underrepresented students in STEM.

experiences and opportunities. There were three catalyzing agents that participants attributed to the CSP program: competence and confidence-building practices, opportunities to participate in undergraduate research, and praise and celebration (see Table 5).

CSP was very intentional about enabling students to improve their math and science competencies and skills so that the participants could achieve academically. Specifically, CSP instructors enhanced the participants' content knowledge and cognitive strategies during the summer program, and academic coaches reinforced these advances during the academic year.

Another tool the program staff used was establishing opportunities for students to participate in undergraduate research. In these spaces, students appreciated connecting knowledge obtained in the classroom setting to real-world science and technology.

Finally, CSP staff incorporated a number of activities and initiatives into the program to praise the students and celebrate their accomplishments. During the summer bridge program, students are recognized for their academic performance in weekly meetings. The program director also nominated students or used formal award ceremonies within the STEM colleges and discipline-based student organizations to acknowledge student success and outcomes.

\section{Proactive Care}

Proactive care undergirds the approach and the work of the CSP staff. Proactive care is an intensive advising strategy that helps students make sense of potential pitfalls (e.g., academic, social, personal) and strategize solutions to overcome these circumstances (see Table 6). Proactive care is used in contrast to reactive approaches that lend support once students experience difficulties. Program staff use admissions data to identify prospective participants who may benefit from the program services and invite them to apply to the program. Once students begin the program, staff work to provide an environment that is "emotionally nurturing and academically rigorous" (Rivera-McCutchen, 2012, para. 3). The program staff are highly involved in the lives of students, ensuring that their transition to college and success therein is predicated on continuous meaningful interactions, care, and support. Findings revealed that the proactive care is a composite of six elements: staff accessibility, trust, positive motivation, reinforcement, encouragement, and student accountability.

\section{DISCUSSION}

The purpose of this study was to use empirical research to develop a model that would explain how STEM enrichment 
TABLE 3. Holistic support

\begin{tabular}{|c|c|c|}
\hline Codes and subcodes & Definition & Participant quotes \\
\hline $\begin{array}{l}\text { Code: Academic } \\
\text { Subcodes: summer instruction } \\
\text { recitation, academic } \\
\text { advising, help-seeking } \\
\text { behaviors, study skills } \\
\text { and habits }\end{array}$ & $\begin{array}{l}\text { Strategies and practices that address } \\
\text { the academic needs of students } \\
\text { and contribute to educationally } \\
\text { purposeful practices (e.g., } \\
\text { studying, attending classes) }\end{array}$ & $\begin{array}{l}\text { [The summer program] gave me a safe place to make all the mistakes I } \\
\text { can't afford to make in the real semester... I was getting those teens } \\
\text { and low 20s, too, but as I was failing that class, I was actually learning } \\
\text { so when I got into the school year, a lot of the material that I had from } \\
\text { the summer, I know. I know how to study. I know how to be } \\
\text { productive because in high school, I did nothing, would still get an A } \\
\text { so now I know I actually have to try so yeah, being in CSP, it let me do } \\
\text { everything that normal freshmen might've made a mistake to do in the } \\
\text { actual school year. It let me do that and not penalize me in the long } \\
\text { run. }\end{array}$ \\
\hline $\begin{array}{l}\text { Code: Transitional } \\
\text { Subcodes: college literacy, } \\
\text { time management, } \\
\text { "bridging" high school } \\
\text { and college }\end{array}$ & $\begin{array}{l}\text { Practices that allowed student to } \\
\text { make a "smooth" transition from } \\
\text { high school to college }\end{array}$ & $\begin{array}{l}\text { I would say CSP kinda gave me the knowledge to know my requirements } \\
\text { before coming in so I knew exactly what prereqs [for the secondary } \\
\text { admissions process] I had to take ... and when to take them ... I } \\
\text { probably would've came in confused and just took classes that I } \\
\text { thought I needed and not being sure of the necessary classes I needed. } \\
\text { And the way that my [course] schedule was set up by Phil and Collin } \\
\text {... led me into the right path of doing it and not having an overloaded } \\
\text { schedule. }\end{array}$ \\
\hline $\begin{array}{l}\text { Code: Psychosocial (specific } \\
\text { to racial climate) }\end{array}$ & $\begin{array}{l}\text { Ways that program administrators } \\
\text { help students understand and } \\
\text { prepare for the racial climate, } \\
\text { isolation, and alienation in STEM } \\
\text { contexts }\end{array}$ & $\begin{array}{l}\text { Phil ... talked about a lot how it will be ... few black engineers and it will } \\
\text { be kinda tough to get used to but to not make it an obstacle ... but use } \\
\text { it as kind of motivation to prove yourself and things like that. We had } \\
\text { a lot of talks ... So we were prepared ... It wasn't something that I } \\
\text { didn't expect. }\end{array}$ \\
\hline Code: Practical & $\begin{array}{l}\text { Support for financial or personal } \\
\text { needs }\end{array}$ & $\begin{array}{l}\text { I know people like [Oshay] definitely pass on their materials and stuff, } \\
\text { just to sort of lessen the financial burden for [students of color]. The } \\
\text { MEP also, with the computers that they have, I know I've had to use it } \\
\text { like several times when mine breaks down and you have to send it in. } \\
\text { You can't really do much as a college student without a computer. }\end{array}$ \\
\hline Code: Professional & $\begin{array}{l}\text { Professional development support } \\
\text { (such as résumé development, } \\
\text { cultivating business acumen, and } \\
\text { strengthening oral/written } \\
\text { communication) }\end{array}$ & $\begin{array}{l}\text { They helped us prepare for career fairs. They were always on us about } \\
\text { updating our résumé. For the National Society of Black Engineers } \\
\text { (NSBE) programs, we had companies ... come by and give presenta- } \\
\text { tions and also offer an internship or a job opportunity ... you always } \\
\text { had to have your résumé prepared for the opportunity. }\end{array}$ \\
\hline
\end{tabular}

programs facilitate retention and degree attainment among underrepresented groups. Using data from a case study of a STEM enrichment program, this investigation illuminated the strategies and practices the program uses to aid in the success of their students. In this discussion, I address the overall model that emerged from this study and the relationships between the various elements. I also highlight how certain elements of the model may be informative concerning certain aspects of the student experience relative to program services and resources.

\section{TABLE 4. Community building}

\begin{tabular}{|c|c|c|}
\hline Code & Definition & Participant quotes \\
\hline $\begin{array}{l}\text { milial } \\
\text { atmosphere }\end{array}$ & $\begin{array}{l}\text { References to the program as a family } \\
\text { or peers and program administra- } \\
\text { tors as extended family members } \\
\text { (e.g., brothers, sisters, fathers) }\end{array}$ & $\begin{array}{l}\text { The people that I met [in CSP] are more of a family to me. I can be on a different } \\
\text { level with the people [in CSP] because it's like a family. I spent six weeks with } \\
\text { these people. I know them on levels that most people don't know them. And so } \\
\text { that's when I feel like I belong. }\end{array}$ \\
\hline $\begin{array}{l}\text { eer-to-peer } \\
\text { relationships }\end{array}$ & $\begin{array}{l}\text { References to relationships with cohort } \\
\text { members who entered the program } \\
\text { in the same year }\end{array}$ & $\begin{array}{l}\text { The relationships you develop in [CSP] were big, especially coming to a big school, } \\
\text { you really don't know anybody, it can be intimidating. So when you come in with } \\
\text { friends and stuff like that, you can be more comfortable trying to focus on school. }\end{array}$ \\
\hline $\begin{array}{l}\text { Relationships } \\
\text { with staff }\end{array}$ & $\begin{array}{l}\text { References to establishing and } \\
\text { maintaining relationships with } \\
\text { program staff }\end{array}$ & $\begin{array}{l}\text { I know that I came in through [a special admissions program] so I had [those] } \\
\text { advisors, but I feel like I had a more one on one relationship with Phil and Collin, } \\
\text { because I spent the summer with them. So you know, I feel closer to them, more } \\
\text { approachable to talk to. }\end{array}$ \\
\hline Peer mentors & $\begin{array}{l}\text { References to relationships with } \\
\text { assigned mentors (and former } \\
\text { program participants) who serve as } \\
\text { resources and guides }\end{array}$ & $\begin{array}{l}\text { [CSP] set you up with those mentors. So you know, from the get go, you're given the } \\
\text { resource of the mentors to ask about really anything. It could be academic, could } \\
\text { be personal. Just something to get you through the program or prepare you for } \\
\text { college. }\end{array}$ \\
\hline
\end{tabular}


TABLE 5. Catalysts for STEM identity development

\begin{tabular}{|c|c|c|}
\hline Code & Definition & Participant quotes \\
\hline $\begin{array}{l}\text { Competence and } \\
\text { confidence- } \\
\text { building practices }\end{array}$ & $\begin{array}{l}\text { Activities that contribute to the cognitive and } \\
\text { psychological benefit of improving one's } \\
\text { understanding, skills, and/or abilities in } \\
\text { STEM content areas }\end{array}$ & $\begin{array}{l}\text { Coming in this summer and being able to take } \ldots \text { those [math] classes } \\
\ldots \text { and gain that knowledge ... definitely gave me a larger sense of } \\
\text { confidence } \ldots \text { if you have that,... [it] will help you push through. }\end{array}$ \\
\hline $\begin{array}{l}\text { Undergraduate } \\
\text { research } \\
\text { experiences }\end{array}$ & $\begin{array}{l}\text { Facilitating STEM identity salience through } \\
\text { engaging students in undergraduate } \\
\text { research experiences }\end{array}$ & $\begin{array}{l}\text { I was actually doing something ... having the responsibility of making } \\
\text { sure that things came out well ... being important to a project. You } \\
\text { know, they still use the data that I [collected] ... to continue on in } \\
\text { their research ... There was one girl ... [who said] I was talking to } \\
\text { [Dr. Bridges] and she was showing me some of your work from last } \\
\text { summer cuz I may work for her.... Oh, she remembers me. I was } \\
\text { actually important, you know. }\end{array}$ \\
\hline Praise and celebration & $\begin{array}{l}\text { Initiatives that facilitate opportunities for } \\
\text { recognition and external demonstrations } \\
\text { of competence (may increase sense of } \\
\text { belonging to STEM) }\end{array}$ & $\begin{array}{l}\text { So, I thought about switching my major and I decided to go to the } \\
\text { [NSBE] Torch Banquet ... they were giving out awards for people } \\
\text { with the highest GPAs and then they mentioned my name and I was } \\
\text { like, what? [I] couldn't believe it. It's just that encouragement ... } \\
\text { small things like that. You need things like that ... a little goes a long } \\
\text { way. }\end{array}$ \\
\hline
\end{tabular}

Model for Programmatic Impact on Retention and Degree Attainment among Underrepresented Students in STEM

Holistic support, community building, and catalysts for STEM identity development comprise the strategies and practices within the program (see Figure 3), thus forming the Venn diagram shown in Figure 3. The overlapping composition of the diagram illustrates the interrelatedness of these elements and their corresponding strategies and practices. For instance, students expressed that, as they strengthened their competencies, they also experienced an increase in their confidence. As students became more competent in their academic subjects, they also became more confident in their identities as STEM persons. Connections could also be found between holistic support and community building. Specifically, the relationships that

TABLE 6. Proactive care

\begin{tabular}{ll}
\hline Code & \multicolumn{1}{c}{ Definition } \\
\hline Staff accessibility & $\begin{array}{l}\text { Being open and available to students as they } \\
\text { encounter hardships; having an awareness } \\
\text { and appreciation for supporting students in } \\
\text { this manner }\end{array}$
\end{tabular}

Trust

Positive motivation

Entailed both motivational messaging directed toward students and approaches that empowered students to regulate their own ability to motivate one's self

Reinforcement

Encouragement

Tendency of the staff to promote or advance attitudes, behaviors, and values that elicit the pursuit of educationally purposeful activities (e.g., studying)

Included reassuring the students that they are capable of success and aiding the students in their educational pursuits

Student accountability Ensures that students understand the expectations of the program (i.e., attitudes and behaviors that support STEM achievement) and holding them responsible for following through
Participant quotes

Being able to have ... people of authority to confide in and ask about different things like scheduling or different conflicts. Just having someone on the phone that I can without hesitation just dial and help me figure things out ... I can't even stress that enough. Having a phone number in my phone that any circumstance ... something is going wrong, like ... I need a new roommate. How do I go about doing this?

Well, what that means is [Collin Davis] already went through school. Mr. Davis, he's already gotten his mechanical engineering degree. They've already done CSP before and they've seen how the trends work. So I figured they know what they're doing. They're the experts so I'm just along for the ride.

I think the program all around has made me a better person because I matured a lot. Before joining the program, I wasn't as motivated as I am now and I didn't have people to push me. Without the program, I probably wouldn't have as much passion as I do because I know so many people [believe] that I can do it, and I [want] to make them proud.

I have biweekly meetings with Phil and Collin so I talk to them about [my academics] and then it was stuff that I kinda already knew, I just didn't do it. So just having them like reiterate it was what got me to do it.

Well I definitely think that the program kept me here ... [For instance,] one of my semesters I was put on academic probation. So I had to like get above a 2.5 to stay here. Phil encouraged me and told me everything I needed to do to [return to good academic standing]. And you know since then my grades haven't dropped that low.

It's easy to talk to like Mr. Smith and the other adults and they help you out, like they make you feel bad for not doing what you're supposed to do or make you feel like you should be doing this, so just do it. I guess it's motivational, in a way. 
students cultivated in the program supported their academic and transitional needs among other areas. Community building and catalysts for STEM identity development overlap with regard to praise and celebration. Within the program, there are formal and informal mechanisms for recognizing academic achievement and success in STEM. Students who earn this recognition feel more affirmed in their identities as STEM persons.

Further, proactive care is represented at the foundation of this model, because it embodies the philosophical underpinnings and approaches to student services within CSP. Program staff proactively engage students to address their academic and social adjustments to college while demonstrating a genuine concern for their success (i.e., college readiness and retention). During the study, it was discovered that the staff's proactive care was boundless with respect to time. The effects of caring continued even beyond the time students were a part of the formalized program. Students continued to seek out support from the program staff, and the staff followed through with care and service to the students.

\section{Academic Services and Support}

Many participants valued that CSP offered many of the services and activities they needed to be successful in college. The "one-stop shop" nature of the office where the program was housed reduced the amount of time and effort needed to navigate the relatively large campus setting to access certain resources (Seymour and Hewitt, 1997). Specifically, students emphasized the importance of academic advising, recitation and tutorial services, and financial and professional support being available within CSP.

Students also noted the differences in CSP's approach to academic advising and what they experienced with university or college advisors. Some students asserted that the university or college advisors were friendly and experts in prescriptive advising, but many lacked the holistic and individualized approach consistent with developmental or proactive advising. Advising literature suggests that, with special student populations, such as the students in the current study, the aforementioned approaches may lack depth (or do not go far enough) to address the systemic and institutional barriers these students have faced (Varney, 2007, 2012). Underrepresented students need more than just course scheduling assistance and periodic notices about institutional policies (e.g., drop/add dates, enrollment dates). Though this information is helpful, it sometimes fails to address the academic and context-specific knowledge necessary to overcome institutional barriers to retention and achievement (Padilla, 2009).

Recitations, which are program-based study sessions, provided space, time, and structure for students to review concepts and receive academic assistance from their coaches and peers. As one student posited, "It's not like we have to make time [or] someone can't make it. It's a designated time. You know where it's at. It's always going to happen that way." The inclusion of recitation simplified the process of designating time to study and engaging in other educationally purposeful activities. It also helped students to more easily locate academic support, because the academic coaches would be available in the space. Research shows tutoring continues to be a staple in the academic lives of students (De Backer et al.,
2012). However, beyond tutorial and academic assistance, what CSP offers is the structure necessary for students to be proactive about studying and opportunities for collaborative learning.

\section{Belonging Experiences}

Having a sense of belonging corresponds to membership in a community, feeling valued and cared about, acceptance, and encouragement (Strayhorn, 2012). Research shows sense of belonging influences student achievement and persistence (Strayhorn, 2012). Community building emerged as a major finding and an important element to the belonging experiences of CSP participants. Unlike Tinto's framework (1987, 1993), which suggested that students should limit their interactions with relationships outside of the college environment to fully integrate into the collegiate context, many students of color rely on their existing relationships with friends and family to persist in higher education (Terenzini et al., 1994). CSP staff and participants use this community to leverage resources, information, and social support.

\section{The Role of STEM Programs in Science Identity Development}

Carlone and Johnson (2007) found that competence, performance, and recognition were central to a salient science identity. Building on this research, many scholars have concluded that science identity salience contributes to student success (Chang et al., 2014). While STEM professionals are best suited to provide disciplinary training and mentoring necessary for STEM identity development and socialization into the disciplines (Seymour, 1999), STEM enrichment programs often play complementary roles in buttressing the academic and professional development of these emerging scientists and engineers (Maton et al., 2000).

Such programmatic catalysts are instrumental in creating environmental conditions that contribute to the STEM identity development of its participants.

\section{Care in Student Services}

Proactive care, as operationalized in CSP, integrates notions of proactive advising (Earl, 1988) and the ethic of care (Gilligan, 1982; Noddings, 1984, 2013). First, the staff were accessible to students and attentive to their needs. They developed bonds and trust with the students such that students felt comfortable seeking out their services when experiencing academic difficulty or needing support in other areas. The students did not perceive the staff as overbearing or parental. In contrast, they described the staffs tactics as genuinely caring about their well-being and success. According to Varney (2007), "[Proactive] advising is not 'hand-holding' or parenting, but rather active concern for a students' academic preparation ... [and a] willingness to assist students" in meeting their academic, professional, and personal goals (para. 2). The staff demonstrated "active concern" through their program development, attention to student needs, and a genuine concern for their well-being and success.

In the present study, the staffs approach to caring seemed to have more depth than proactive advising alone. Though care has been identified as an element within proactive advising, the caring aspect of the staffs approach with students was relational, situational, and individualized. In an article documenting the 
practices of Towson University's administrators, Woodus indicated that intrusive caring was "gently but firmly prying into every aspect of the freshman's life, probing for problems" (de Vise, 2010, para. 22). For administrators to effectively "probe," they must first establish a trusting relationship with the student. Due to this initial step, CSP staff knew how to show care for different kinds of students. Their interactions were differentiated. Some students they were stern and direct with, while to others they showed more compassion and empathy for their circumstances. The staff was able to respond in these varied ways only because they knew their students; they understood their circumstances; and they wanted to help them advance their lives through the attainment of a STEM degree.

CSP staff spent a considerable amount of time getting to know the students and their backgrounds, goals, and aspirations. CSP's attention to the whole person influenced the program's ability to get results and motivated students to fully engage in the program components. Strayhorn's (2012) research on sense of belonging concurs with these findings. According to Strayhorn (2012), "When needs are met, optimal functioning is possible," such that students perform well academically when they feel like they belong (p. 74). Though program activities were mandatory, there were no institutional policies requiring students to stay in the program. The students stayed because they wanted to, and they saw significant gains in their development. In the broadest sense, these behaviors and outcomes attune to educational learning goals: cognitive, affective, and psychomotor (Guskey, 2013). The students made cognitive gains, they felt good about themselves and their abilities, and they demonstrated their knowledge in an academic context. The achievement of these learning goals was predicated on a foundation of proactive care established by the CSP staff.

\section{IMPLICATIONS}

Program administrators should also consider frameworks such as the proposed model to plan and implement STEM enrichment programs. Holistic support elements may help administrators to reverse engineer their programs through considering what evidence-based challenges (e.g., particular gateway courses, scheduling combinations) exist in the institution and how developing an intervention can mitigate potential impediments to student success. Community building considers what environmental factors and institutional agents may be influential in creating experiences in which students feel valued and cared about. How administrators create belonging experiences will depend on the institutional contexts and available resources (e.g., financial, human capital). Catalysts for STEM identity development can assist administrators in thinking about activities and services that might promote confidence. Finally, proactive care aids administrators in considering approaches that humanize the educational experiences of underrepresented groups in the STEM disciplines (Museus and Liverman, 2010). Noddings (1984) conjectured that caring behaviors in educational environments can influence student motivation. Though much of her research focused on K-12 contexts, the current study shows that the notion of caring is equally relevant to postsecondary education environments.

The proposed model can also be instrumental in developing an infrastructure for assessment, evaluation, and research for enrichment programs. As greater accountability increases from institutional and national funding sources, identifying innovative and complex ways to measure student outcomes and success is necessary to acquire and sustain funding (Espinosa and Rodríguez, 2013). The onus is often placed on the individual programs to prove their value. This model provides cognitive and noncognitive factors that are leading indicators of program outcomes and impacts. Program administrators can collaborate with institutional researchers to generate quantitative data on areas such as performance in individual courses and involvement in undergraduate research. Additionally, program administrators should use qualitative methods such as journaling, focus groups, and open-ended surveys to capture students' program experiences.

\section{CONCLUSION}

Previous studies have investigated a number of factors that contribute to the success of underrepresented students in the STEM disciplines (Fullilove and Treisman, 1990; Maton et al., 2000; Cole and Espinoza, 2008), but few studies provide an explanation for the efficacy of STEM enrichment programs. Many of these studies illuminated individual and institutional attributes that support student achievement, but they failed to consider the complexities and nuances of the role of STEM enrichment program, beyond serving as a conduit for academic and social integration (Tsui, 2007). Some researchers refer to the college experience as the black box, because it is difficult to determine what elements contribute to student retention or attrition (Padilla, 2009). In the current study, an integrated conceptual framework that explored facets of student success, sense of belonging, science identity, and notions of care in a STEM enrichment program elucidated a multifaceted model for understanding and explaining the inner workings of the program and subsequent student outcomes.

\section{ACKNOWLEDGMENTS}

This study was made possible in part through funding from Michigan State University's College of Education. The funding agency made no contribution to design, data collection, interpretation, or publication of this study.

\section{REFERENCES}

Barrena JC, Veden MJ (producers) (2013). LSAMP: Aiming High and Making a Difference. www.youtube.com/watch?v=53y7QJoH7Co (accessed 1 April 2015)

Bordogna J (2012, September 12). Taking LSAMP into the future. Speech delivered at Howard University in Washington, DC. www.nsf.gov/news/ speeches/bordogna/jb020912lsamp.htm (accessed 1 April 2015).

Braxton JM (2000). Reworking the Student Departure Puzzle, Nashville, TN: Vanderbilt University Press.

Carlone HB, Johnson A (2007). Understanding the science experiences of successful women of color: science identity as an analytic lens. J Res Sci Teach 44, 1187-1218

Chang MJ, Sharkness J, Hurtado S, Newman CB (2014). What matters in college for retaining aspiring scientists and engineers from underrepresented racial groups. J Res Sci Teach 51, 555-580.

Charmaz K (2008). Grounded theory as an emergent method. In: Handbook of Emergent Methods, ed. SN Hesse-Biber and P Leavy, New York: Guilford, 155-170. 
Chemers MM, Zurbriggen EL, Syed M, Goza BK, Bearman S (2011). The role of efficacy and identity in science career commitment among underrepresented minority students. J Soc Issues 67, 469-491.

Chen X (2009). Stats in Brief: Students Who Study Science, Technology, Engineering, and Mathematics (STEM) in Postsecondary Education (NCES 2009-161), Washington, DC: National Center for Education Statistics, U.S. Department of Education. http://files.eric.ed.gov/fulltext/ED506035 .pdf (accessed 1 March 2013).

Cole D, Espinoza A (2008). Examining the academic success of Latino students in science technology engineering and mathematics (STEM) majors. J Coll Stud Dev 49, 285-300.

De Backer L, Van Keer H, Valcke M (2012). Exploring the potential impact of reciprocal peer tutoring on higher education students' metacognitive knowledge and regulation. Instr Sci 40, 559-588.

de Vise D (2010, December 12). In higher education, lessons in equality. Washington Post. www.washingtonpost.com/wp-dyn/content/article/ 2010/12/11/AR2010121103154_pf.html (accessed 28 February 2015)

Eagan MK, Hurtado S, Chang MJ, Garcia GA, Herrera FA, Garibay JC (2013). Making a difference in science education: the impact of undergraduate research programs. Am Educ Res J 50, 683-713.

Earl WR (1988). Intrusive advising of freshmen in academic difficulty. NACADA J 8(2), 27-33.

Espinosa LL, Rodríguez C (2013). Broadening participation in STEM. In: Fostering Success of Ethnic and Racial Minorities in STEM, ed. RT Palmer. DC Maramba, and M Gasman, New York: Routledge, 130-141.

Fullilove RE, Treisman PU (1990). Mathematics achievement among African American undergraduates at the University of California, Berkeley: an evaluation of the mathematics workshop program. J Negro Educ 59, 463-478.

Gilligan C (1982). In a Different Voice, Boston, MA: Harvard University Press.

Guskey TR (2013). Defining student achievement. In: International Guide to Student Achievement, ed. J Hattie and EM Anderman, New York: Routledge, 3-6.

Hausmann LR, Ye F, Schofield JW, Woods RL (2009). Sense of belonging and persistence in white and African American first-year students. Res High Educ 50, 649-669.

Hayes RQ (2002). 2001-02 STEM Retention Report: The Retention and Graduation Rates of 1994-2000 Freshman Cohorts Entering Science, Technology, Engineering and Mathematics Majors in 200 Colleges and Universities, Norman, OK: Consortium for Student Retention Data Exchange.

Hurtado S, Carter DF (1997). Effects of college transition and perceptions of the campus racial climate on Latino college students' sense of belonging. Sociol Educ 70, 324-345

Hurtado S, Eagan MK, Tran MC, Newman CB, Chang MJ, Velasco P (2011). "We do science here": underrepresented students' interactions with faculty in different college contexts. J Soc Issues 67, 553-579.

Johnson DR, Soldner M, Leonard JB, Alvarez P, Inkelas KK, Rowan-Kenyon $H T$, Longbeam SD (2007). Examining sense of belonging among firstyear undergraduates from different racial/ethnic groups. J College Student Dev 48, 525-542.

Kuh GD, Kinzie J, Schuh JH, Whitt EJ, et al. (2010). Student Success in College: Creating Conditions That Matter, San Francisco: Jossey-Bass.

Locks AM, Hurtado S, Bowman NA, Oseguera L (2008). Extending notions of campus climate and diversity to students' transition to college. Rev High Educ 31, 257-285.

Manning K, Kinzie J, Schuh J (2006). One Size Does Not Fit All (1st ed.), New York: Routledge.

Maton KI, Hrabowski FA, Schmitt CL (2000). African American college students excelling in the sciences: college and post college outcomes in the Meyerhoff Scholars Program. J Res Sci Teach 37, 629-654.

Merolla DM, Serpe RT (2013). STEM enrichment programs and graduate school matriculation: the role of science identity salience. Soc Psychol Educ 16, 575-597.

Museus SD (2014). Asian American Students in Higher Education, New York: Routledge.
Museus SD, Liverman D (2010). Analyzing high-performing institutions: implications for studying minority students in STEM. New Dir Inst Res 148 17-27.

Museus SD, Palmer RT, Davis RJ, Maramba D (2011). Special issue: Racial and ethnic minority students' success in STEM education. ASHE High Educ Rep 36(6), 1-140.

National Academy of Sciences, National Academy of Engineering, and Institute of Medicine (2010). Expanding Underrepresented Minority Participation: America's Science and Technology Talent at the Crossroads and the Expansion of the Science and Engineering Workforce Pipeline, Washington, DC National Academies Press.

National Science Foundation (2015). Women, Minorities, and Persons with Disabilities in Science and Engineering: 2015, Special Report NSF 15-311, Arlington, VA. www.nsf.gov/statistics/wmpd (accessed 1 April 2015).

Noddings N (1984). Caring: A Feminine Approach to Ethics and Moral Education Berkeley: University of California Press.

Noddings N (2013). Caring: A Relational Approach to Ethics and Moral Education, Los Angeles: University of California Press.

Padilla RV (2009). Student Success Modeling: Elementary School to College, Sterling, VA: Stylus.

Rendon LI, Jalomo RE, Nora A (2000). Theoretical considerations in the study of minority student retention in higher education. In: Reworking the Student Departure Puzzle, ed. JM Braxton, Nashville, TN: Vanderbilt University Press, 127-156.

Rivera-McCutchen RL (2012). Caring in a small urban high school: a complicated success. Urban Educ 47, 653-680.

Sedlacek WE (2004). Beyond the Big Test: Noncognitive Assessment in Higher Education, San Francisco, CA: Jossey-Bass.

Seymour E (1999). The role of socialization in shaping the career-related choices of undergraduate women in science, mathematics, and engineering majors. Ann NY Acad Sci 869, 118-126.

Seymour E, Hewitt NM (1997). Talking about Leaving: Why Undergraduates Leave the Sciences, Boulder, CO: Westview.

Stake RE (2000). Case studies. In: Handbook of Qualitative Research, ed. NK Denzin and YS Lincoln, Thousand Oaks, CA: Sage, 435-454.

Stolle-McAllister K, Domingo MRS, Carrillo A (2011). The Meyerhoff way: how the Meyerhoff Scholarship Program helps black students succeed in the sciences. J Sci Educ Technol 20, 5-16.

Strayhorn TL (2012). College Students' Sense of Belonging: A Key to Educational Success for All Students, New York: Routledge.

Terenzini PT, Rendon LI, Upcraft ML, Millar SB, Allison KW, Gregg PL, Jalomo $\mathrm{R}$ (1994). The transition to college: diverse students, diverse stories. Res High Educ 35, 57-73.

Tierney WG (1992). An anthropological analysis of student participation in college. J High Educ 63, 603-618.

Tinto V (1975). Dropout from higher education: a theoretical synthesis of recent research. Rev Educ Res 45, 89-125.

Tinto V (1987). Leaving College: Rethinking the Causes and Cures of Student Attrition (1st ed.), Chicago, IL: University of Chicago Press.

Tinto V (1993). Leaving College: Rethinking the Causes and Cures of Student Attrition (2nd ed.), Chicago, IL: University of Chicago Press.

Treisman U (1992). Studying students studying calculus: a look at the lives of minority mathematics students in college. Coll Math J 23, 362-372.

Tsui $L$ (2007). Effective strategies to increase diversity in STEM fields: a review of the research literature. J Negro Educ 76, 555-581.

Varney J (2007). Intrusive advising. Acad Advising Today 30, 11

Varney J (2012). Proactive (intrusive) advising. Acad Advising Today 35(3).

Watson K, Froyd J (2007). Diversifying the U.S engineering workforce: a new model. J Eng Educ 96, 19-32.

Westat (2000). A Description and Analysis of Programs Promoting Participation of Underrepresented Undergraduate Students in Science, Mathematics, Engineering, and Technology Fields (NSF 01-31), Arlington, VA: National Science Foundation.

Yin RK (2003). Case Study Research: Design and Methods, Thousand Oaks, CA: Sage. 